Harris, C. S., \& Winter, J. S. (2013). "Opening the flow of citizen engagement: An exploratory study of social networking services as a potential vehicle for e-participation in the City and County of Honolulu." International Journal of Electronic Government Research, 9(2), 63-84. doi:10.4018/jegr.2013040104.

\title{
An exploratory study of social networking services as a potential vehicle for e- participation in the City and County of Honolulu
}

\author{
Cassandra S. Harris and Jenifer Sunrise Winter \\ School of Communications \\ University of Hawaii at Manoa
}

\begin{abstract}
This study examined the use of Social Networking Services (SNS) by policymakers in the City and County of Honolulu. Interviews identified policymakers' main reasons for using SNS, examined how SNS was integrated into the policymaking process, and also highlighted issues faced in deploying SNS for government services. The City and County informally initiated use of SNS in 2008, and use remained at an early stage of integration into business processes and operations at the time of this study. Government-operated SNS was primarily used as a one-wayinformation-based service. In this early stage, SNS was not being used to directly promote eparticipation initiatives, although potential future uses were discussed. Government officials noted a spectrum of desired expectations regarding future development of SNS. We recommend an agency-wide use policy be created to provide for consistency of use across administrations and that a formal pilot study, addressing the perspectives of multiple stakeholders, be initiated.
\end{abstract}

Keywords: E-participation, Social Networking Services, E-democracy, policy, local government

\section{Introduction}


Information and communication technologies (ICTs), as potential catalysts for increased political participation and democratic enhancement, are increasingly part of academic discourse. Advancements in online media and further analysis of ICTs' influence on public participation are shifting such research from theoretical context to pragmatic understanding, investigation, application, and empirical research (Boyd, 2008). In particular, social networking services (SNS) like Facebook and Twitter provide valuable insight into the practices and theories of citizen engagement (Sæbø, Rose, \& Nyvang 2009; Taylor-Smith \& Lindner, 2009). While there has been a great deal of discussion about the potential for SNS as a tool for citizen engagement, the success of these technologies in engaging citizens, particularly at municipal levels, is undetermined. This study provides a case example of a large city in the United States in the early stages of employing SNS for government services.

The United Nations Department of Economic and Social Affairs Division for Public Administration and Development Management (2008) suggests that modern e-government systems should assess the potential application and associated benefits of moving towards connected governance, which offers a systematic approach to the collection, reuse and sharing of data and information. As governments further examine providing a greater interactive participatory quality to the modern online public sphere, e-government systems will inevitably need to be designed to help mold patterns of communication, influence social values, and ultimately benefit the public (Brewer, Neubauer, \& Giselhart, 2006).

In its early form, e-government was generally understood as a provision of government services by means of ICTs, allowing public administrators to provide traditional public services in a new and more efficient way, while at the same time offering new forms and types of services (Arjuna, Pradovani, \& Nesti, 2007). E-government systems deliver services electronically to focus on 
Harris, C. S., \& Winter, J. S. (2013). "Opening the flow of citizen engagement: An exploratory study of social networking services as a potential vehicle for e-participation in the City and County of Honolulu." International Journal of Electronic Government Research, 9(2), 63-84. doi:10.4018/jegr.2013040104.

citizens' needs by offering information and enhanced services that enable stakeholders to influence government operations (Lappas, 2008). More recently, the promise of e-government has expanded to not only include the provision of quality government services and delivery systems, but also to the engagement of citizens in government (Bertot, Jaeger \& McClure, 2008).

ICT-enabled developments in the public sector raise important empirical questions about the impact that emerging information and communication environments have on the relationship between government and citizens (Lips, 2010). As government bodies evaluate the move toward SNS it is critical to garner how, if at all, new information/communication exchanges impact the existing relationship between government and citizens.

In democracies, municipalities support state institutions through implementing national government policies as well as by responding to the needs of local residents (Nachmias \& Rotem, 2007). The public sector use of ICTs to enhance citizen participation has seen continual development through the deployment of public-involvement programs at national, regional, and local levels (Scott, 2006). SNS, as widely accessible two-way communication vehicles, are being increasingly recognized by practitioners as key tools for a subset of e-government called "eparticipation" (Sæbø et al., 2009). However, the potential for SNS as a tool for e-participation in the policymaking process has only recently gained attention in research, and little focus to date has been placed on the potentials for local governments. In order to further understand SNS as portals for e-participation, it will be important to understand the barriers of implementation and use by practitioners. The implementation of modern e-government practices produces unique challenges to local authorities who must consider balancing attention to residents' needs and opinions with maintaining strong governance without slowing down the local policy process 
(Nachmias \& Rotem, 2007). Particularly, in reviewing local governments' interaction with ICTs, Kling (2000) found that, due to the combination of equipment, people, and governance structures, ICT policies differed from one city to the next. This sociotechnical approach is also adopted by Sæbø et al. (2009), who argue that growth in SNS is driven by technical, social, economic and institutional forces. While local governments share some of the e-government requirements with those at the national level, they also maintain specific requirements that are either unique to their contexts or stipulate greater examination (Löfstedt, 2005). Similarly, Mann, Grant, and Mann (2011) compared elements and services of city e-government initiatives and concluded that the scope of each was unique, emphasizing the need to customize e-government services to the local needs of citizens. Following a sociotechnical, network society perspective (Castells, 1996, 2009), we argue that the rise of modern ICT networks is inextricably bound with sociocultural, organizational, political and economic dimensions of society and represents the emergence of new forms of networked relationships between governments and citizens, as well as within governments. This network society lens enables us to focus on the reconfiguration of social and organizational relationships via e-government service provisions.

Within the context of creating participatory forums, there are several challenges to utilizing the Internet, including "ensuring access for all interested individuals, fair and equal involvement for all participants, development of interpersonal trust, and the ability to produce effective dialogue on complex, value-laden issues" (Romsdahl, 2005, p. 2). SNS can be considered a logical tool for bridging the gaps that prevent e-participation from being incorporated into the public's lives through increasing general awareness of the issues, making e-participation platforms more accessible to audiences otherwise not engaged in political debate, and making users' participation easier and more intuitive (Lacigova, Maizite, \& Cave, 2012). Recently, 
Harris, C. S., \& Winter, J. S. (2013). "Opening the flow of citizen engagement: An exploratory study of social networking services as a potential vehicle for e-participation in the City and County of Honolulu." International Journal of Electronic Government Research, 9(2), 63-84. doi:10.4018/jegr.2013040104.

governments have started using SNS to achieve wider interaction with citizens; however, faced with the lack of developed practices, they currently find themselves limited to isolated, fragmented and non-coordinated use of SNS (Charalabidis, Loukis, \& Kleinsfeld, 2012). Thus, greater knowledge is needed to better understand how government agencies can effectively use SNS to promote and enhance participative public policy-making (Charalabidis, et al., 2012).

This study is timely, as governments around the world continue to evaluate and integrate SNS into their overall communication efforts. To enhance understanding of SNS use by local government, this research provides insight into the employment of SNS by the City and County of Honolulu. Particularly, this research adds to the theoretical and pragmatic understanding of eparticipation through the investigation and evaluation of unique, as well as common, opportunities and barriers to implementing SNS as potential platforms for e-participation. We believe that our study will be useful to policymakers looking to utilize SNS to promote citizen participation in the policymaking process. Further, this study adds to the academic field of egovernment through the provision of insight into stakeholders' perceptions of local eparticipation through government-operated SNS.

This paper begins with a summary of literature related to SNS and e-participation, describes the interview process used to explore SNS use within the City and County of Honolulu, and presents summary findings of this case. We conclude with an outline of the theoretical and practical contributions of this study.

\section{SNS and e-participation}


Considering the wide array of ICTs with the potential to support participation, it becomes a critical challenge to offer participatory channels for the user (Harris \& Vincent, 2008). A primary problem with these existing communication tools, such as chat technologies, discussion forums, and group decision support systems, is their ability to engage citizens. The ability of SNS to attract and sustain interaction, support content generation, provide forums of discussion and attract large numbers of users appears to solve some of the problems of engaging users that other e-participation services struggle with (Sæbø, Rose, \& Nyvang, 2009). As an integral part of Web 2.0 technologies, SNS are characterized by user-generated content, multi-way communication, and various other new-media based capabilities (Robertson, Vatrapu, \& Medina, 2009). The use of SNS in citizen/government communication has been described as "Government 2.0" (Chun, Shulman, Sandoval, \& Hovy, 2010). However, the success of these technologies in engaging citizens is still undetermined.

The heightened transparency and awareness in established democracies in conjunction with the rapid emergence of social revolutions in countries like Tunisia and Egypt have highlighted how growth in online infrastructure and SNS have aided in the facilitation of social change (Roy, 2012). Government-based participatory initiatives utilizing SNS include Germany's "Aufwachsen mit dem Netz" and "Aufbruch Bayern", and the United Kingdom's "Citizen Space" (Buhl, 2011). Within the example of "Aufbruch Bayern," Free State of Bavaria citizens were provided with the opportunity to participate in an eight-week online public dialogue with the Bavarian State Government (Buhl, 2011). Aided by SNS tools like Facebook, Twitter, and YouTube, 100,000 participants discussed and evaluated 740 user-generated suggestions and ideas concerning topics related to family, education, and innovation. The best contributions were discussed in regards to feasibility by the Bavarian Council of Ministers. Government has also 
Harris, C. S., \& Winter, J. S. (2013). "Opening the flow of citizen engagement: An exploratory study of social networking services as a potential vehicle for e-participation in the City and County of Honolulu." International Journal of Electronic Government Research, 9(2), 63-84. doi:10.4018/jegr.2013040104.

leveraged SNS as platforms to update the public during emergencies and periods of unrest. For instance, during the 2011 London riots, government used Twitter to provide official updates or clarifications about rumors, as well as replies to citizen queries (Panagiotopoulos \& Sams, 2011). As the emergence of SNS changes the social dynamics of everyday life, a shift in government understanding and action is required to meet citizens' evolving expectations (Budinoski \& Trajkovik, 2012).

Although there has been a growth in support for using SNS in e-participation initiatives, the nature and scale of the impacts and challenges for policy making are still difficult to evaluate (Mota \& Santinha, 2012). While SNS provides a potential to solve some of the problems faced by e-participation services, it has not solved the democratic challenges posed by lack of participation (Sæbø et al., 2009). The potential for SNS as a government tool for e-participation is just beginning to receive greater attention in research, with broad focus being placed on the potentials for local municipalities. In order to further understand SNS as a portal for eparticipation, it will be important to understand the barriers of implementation and use by practitioners and citizens at all government levels: international, national, and local.

This research investigated and evaluated opportunities and barriers to implementing SNS as potential platforms for e-participation in the City and County of Honolulu by examining the use of SNS by policymakers. It identified the current state of SNS use in providing government services, probed policymakers' main reasons for using these services, examined how they were integrated into the policymaking process, and also identified issues faced in deploying SNS for government services. Specifically, we examine the use of Twitter and Facebook. Each of these tools has specific affordances that may enable or constrain citizen interaction with government. 
Chun et al. (2010) emphasize the limited character space of microblogs like Twitter and note that they are typically used to share information about current events or personal opinions. Twitter is less conducive to two-way communication, allowing users to submit short status updates (called tweets) while following the updates of others (Phelan, McCarthy, \& Smyth, 2009). Facebook's structure is open, with behavioral norms and a variety of tools that enable members "to create their profile, display a picture, accumulate and connect to friends met both online and offline and view each other's profile..." (Papacharissi, 2009, p.200). Facebook may enable formation of virtual communities and sharing multimedia information. Both tools are not static but evolve and employ, to varying degrees, other features such as RSS feeds and social bookmarking or tagging. Furthermore, because they are both socially constructed and interpreted, each tool has interpretive flexibility, different meanings assigned by various groups (Pinch \& Bijker, 1987).

\section{Methods}

To explore SNS use within the City and County of Honolulu and future potential as platforms for local e-participation, interviews were administered during the fall of 2010. Semi-structured interviews were employed to ensure the same sets of questions were used in each interview, while allowing the flexibility to follow important paths. All interviews except one, the Department of Transportation (DTS), were conducted in person via on-site visits. Interview questions were delivered to and completed by DTS officials via email. All face-to-face interviews were recorded, transcribed, and copies were emailed to participants to review for accuracy, strengthening objectivity and credibility. We used the network society perspective to frame our questions, and the development of interview questions and analysis was further guided by an analytic framework developed by Macintosh (2004), which was chosen for its comprehensive list of factors useful for evaluating e-participation initiatives (based on earlier 
Harris, C. S., \& Winter, J. S. (2013). "Opening the flow of citizen engagement: An exploratory study of social networking services as a potential vehicle for e-participation in the City and County of Honolulu." International Journal of Electronic Government Research, 9(2), 63-84. doi:10.4018/jegr.2013040104.

levels of engagement proposed by the OECD). Macintosh's framework addresses the role of ICTs in participation and helps to characterize and to understand early case studies and identify conditions under which best practices can emerge. Qualitative analysis of the complete transcripts was used to develop themes as they emerged. Transcripts were read multiple times, and then coding categories were developed by reading and marking the transcripts until saturation occurred (Creswell, 1998). Tables were then constructed to assist with repeated coding of the transcripts and led to the emergence of a number of categories. Individual responses were classified in the table and linked to individual participants. After categories were formed, single instances were examined and patterns were sought between categories (Stake, 1995). When coding was finalized, data were summarized thematically, and clarifying questions were asked.

Interview questions sought to gain insight into the following: Policymakers' rationale for using SNS in government services, SNS integration at each stage of the policymaking process, the level of citizen participation promoted, perceptions of the main problems and benefits of SNS deployment, and future plans to integrate SNS. Participants were elicited based on their current involvement with government SNS. Policymakers are defined in the study's context to be public administrators who were managing, or intending to manage, official City and County Facebook or Twitter accounts. The Chief Information Officer of the City and County provided a list of departments using SNS, and additional participants were located using snowball sampling. Table 1 provides a snapshot of the interview questions employed during data collection; the questions are organized by insights sought. An initial group of questions explored the rationale for using SNS and sought to understand its present implementation in City and County 
government services. Additional questions investigated SNS integration in the policymaking process. Tambouris, Liotas, and Tarabanis (2007) observe that this requires identifying the stage of the policy life cycle that a particular ICT tool is associated with. The OECD (2003) describes five stages: agenda setting, analysis, creating, implementing, and monitoring.

Other questions sought to identify the degree of citizen engagement desired by the policymaker. The International Organization for Economic Co-operation and Development (2001) identifies three levels of citizens' engagement that can be supported by ICTs: informational, consultational, and active participation. At the informational level, citizens receive one-way access to relevant information via electronic means; at the consultation level, governments interact with citizens through electronic mechanisms that provide for a two-way feedback; and active participation is based on a partnership with the government and citizens. At this level, citizens actively engage in the policy-making process and are acknowledged in the dialogue (OECD, 2001; OECD, 2003). Macintosh (2004) and Macintosh and Whyte (2008) further developed these categories to describe three levels of participation used in this study: E-enabling, E-engaging, and E-empowering. E-enabling addresses the availability and understandability of information provided through technology. E-engaging is concerned with the top-down use of technology to engage citizens. E-empowering is concerned with supporting active participation and facilitating bottom-up ideas to influence the political agenda. These address how to engage citizens in government activities via ICTs.

Finally, additional questions explored perception of the main problems and benefits related to government use of SNS, as well as policymakers' future plans to integrate SNS to engage the public.

\section{Results}


Harris, C. S., \& Winter, J. S. (2013). "Opening the flow of citizen engagement: An exploratory study of social networking services as a potential vehicle for e-participation in the City and County of Honolulu." International Journal of Electronic Government Research, 9(2), 63-84. doi:10.4018/jegr.2013040104.

Policymakers from five City and County units, Department of Transportation Services (DTS), Department of Information Technology (DIT), Department of Design and Construction (DDC), Office of the Mayor (Mayor), and Department of Budget and Finance (DBF), were interviewed. Due to their involvement with SNS, three individuals from the DDC were interviewed and two individuals from the DIT were interviewed, leading to a total of eight interviewees.

\section{Rationale for SNS Deployment}

All departments interviewed utilized Twitter, though only one of the five (DTS) utilized

Facebook. DTS initiated its Facebook page in early 2009 as part of an overall integrated communication strategy for the department's Honolulu Rail Transit Project. It was noted that rail has been publicly debated in Hawaii since the 1960s, and recent efforts to gain political and public support for rail transit have led to contentious public debate (Platte, 2008).

The use of Twitter by all departments was primarily driven by the DIT, specifically the Chief Information Officer's (CIO) recommendation to the Mayor, who approved its implementation for all City and County departments. The CIO's motivation was to make emerging technologies available without specifying how they might aid in accomplishing the organization's mission. Specific uses evolved over time on an individual department basis, depending upon organizational need and the judgment and experience of the responsible manager. Thus, use of Twitter was initiated in 2008 on a department-by-department basis with no overall use policy. The DIT explains:

The introduction of Twitter to the City was an IT proposal to keep the City up to date with the latest tools for government. We pitched it to the Mayor who embraced it and asked the City to run with it. Because each department has its own needs and challenges, 
it was left to them to decide how to apply this potentially powerful tool. The IT department served merely as a facilitator; we helped to standardize the account names and provided technical support for nascent efforts.

One reason cited for the DIT's decision to foster departmental Twitter accounts was as a preventative measure against the development of counterfeit City and County agency Twitter accounts.

Because uses of Twitter evolved more or less independently in each department, notable similarities and differences emerged (Table 2). These are outlined below.

\section{Receiving and Relaying Peer Agency Information}

From the outset of Twitter availability and deployment, some departments started to follow Twitter feeds of governments and agencies with similar missions, to gain knowledge regarding how peer agencies utilize Twitter. A member of the DDC observed:

The other thing I've done is try to link to other similar governmental organizations. For example, I'm following 3 or 4 other City organizations that have the same mission, to see what kinds of things they publicize in their Twitter. I try to follow them, and some of them are following me so we can learn from each other.

While the original linking of peer organizations was viewed as a way to better understand what types of information similar organizations were publicizing on Twitter, the DDC implementation highlighted how that application extended to a rudimentary integration into business processes by making ongoing project status more easily available, both internally and externally:

Part of it was for us to figure out what the rest of the world, in the engineering and construction industry, was doing on Twitter. So in my attempts to get sample Twitter 
Harris, C. S., \& Winter, J. S. (2013). "Opening the flow of citizen engagement: An exploratory study of social networking services as a potential vehicle for e-participation in the City and County of Honolulu." International Journal of Electronic Government Research, 9(2), 63-84. doi:10.4018/jegr.2013040104.

feeds from other DDCs throughout the nation, I found out they do similar things we have as to projects or they will link to the status reports regarding what's going on with their program.

Similarly, one member of the DIT began to follow peer organization's tweets as a way to maintain up-to-date professional developments information.

There was evidence of re-tweeting to share another agency's posted information with a government's own Twitter constituents, as noted by the Mayor's representative:

Let's say that somebody in one of our departments realizes... there is a bad accident and the freeways are closed. And, maybe they tweet that before I get the information to tweet. Then I will see that, and I will think: I should share this, too. Because the Mayor's Office has many more followers, so this would help disseminate that information to a wider audience. So I will either re-tweet that, or maybe I will re-tweet it and make a call, get more information, and update it. Or when the accident is finally cleared, I'll put that information out.

Thus, re-tweeting allowed more individuals, who might not have been following the particular City and County account that sent out the initial message, to also receive the information relayed in the initial message, thus extending the audience reach. In this instance, the Mayor's representative also described the process of following-up with the original sender of the message as well as the event or incident. 
One DIT official described using Twitter to receive and pass on professional tweets from nonpublic officials. Information received from professional updates on Twitter was sometimes used to stay informed about emerging events. This information also assisted government in reacting to information that could potentially impact operations. In one example, breaking news about a major fiber cable break affecting Internet coverage throughout the state was tweeted by a company's owner and a member of DIT used this information to notify the City \& County's technology operations group.

In other cases, non-governmental accounts were leveraged as a way to receive emerging, emergency-based information. For instance, DIT reported use of a Twitter feed called ktlink to monitor real-time traffic incident reports on the island of Oahu:

The ktlink that shows every traffic accident as it happens. Strips it off the Police Department website... So I know there is an accident at the corner of A and B Street. Before anybody knows. Because it got real-time rebroadcasted from the Police website. This demonstrates a fruitful collaboration between citizens and government.

\section{Monitoring Breaking News}

Some participants saw Twitter as a useful monitoring system for emerging news and events. In this regard, Twitter was noted for its capacity to instantaneously relay information, and as a firststop news portal. In the case of monitoring breaking news and ongoing events, government use portrayed as benefitting internal use via re-tweets or through departmental tweets was noted. The use was as a receiver of information in order to keep informed of real-time events, which might have a time delay if received via other more traditional news media, such as television.

\section{Pushing Information to the Public}


Harris, C. S., \& Winter, J. S. (2013). "Opening the flow of citizen engagement: An exploratory study of social networking services as a potential vehicle for e-participation in the City and County of Honolulu." International Journal of Electronic Government Research, 9(2), 63-84. doi:10.4018/jegr.2013040104.

It was frequently noted by participants that Twitter was being leveraged primarily as a one-way communication tool to push information out to the public. While the usage was consistent, the types of information varied from department to department. For instance, DDC provided select information from official documents, thus providing a push rather than pull mechanism by placing information in one place. One member of the DDC noted, "We've been just providing information that is already public knowledge or is an official document. Nothing controversial..." Another type of information push is the notification of City and County activities and events:

For our Department, [use is] primarily to inform the public of our activities. We do the design and construction for most of the Capital Improvement Program. And as you execute there are situations where you want to notify the public, like where we have to close roads for a specific project. So one of the things I put out every week is a "Road Closure Report." When we have events like groundbreakings or finish of a construction project [...], you may see it on TV or newspapers, or we'll put out a press release. So I'll usually link to those media events with Twitter messages.

A DIT representative described Twitter use as a response portal to citizen requests for more "passive" information: "For example, we were involved in applying for the Google "Broadband" grant. And so, we were getting a lot of calls. And the way I responded was: 'Just look at Twitter, and we will tell you what happened."

In one instance, one-way communication streams broadcast from government were described as an extension of an appointed official's personality. The Mayor's representative reported that Twitter was sometimes used as an extension of the Mayor's personality by communicating 
noncritical and nongovernmental information, such as congratulating local athletic teams for achievements.

The DTS representative reported using Facebook, in concert with Twitter, YouTube and Vimeo, to push information to interested parties by allowing the department, “...to reach different audiences to provide information to people who want to learn more about the project". Thus, the goal of this initiative is to provide information to a specific demographic who are narrowly defined as being interested in learning, or staying informed, about the Honolulu Rail Transit project.

DTS also utilized public feedback from Facebook to adjust information delivered to meet the concerns and or needs of its members:

It's used as feedback on the project and also helps inform our messaging. For instance, if there are questions around a certain topic, then we can adjust our efforts to provide more information to the public in that particular area. Feedback is particularly important on a project of this size and scope.

In this case, the government actively reads and responds to public activity on Facebook through leveraging trends in topic and question type to discern public interest to adjust their information going forward. This does not imply that the public was able to participate via Facebook in the overall policy-making process regarding rail. However, citizens could participate in the decisionmaking process regarding the type of information desired from government.

The stated goal of the DTS Facebook initiative was "to connect with the community and educate the general public on the project". In this sense, education is perceived as the focus of the information delivered, whereas connecting refers to the perspective from which Facebook is 
Harris, C. S., \& Winter, J. S. (2013). "Opening the flow of citizen engagement: An exploratory study of social networking services as a potential vehicle for e-participation in the City and County of Honolulu." International Journal of Electronic Government Research, 9(2), 63-84. doi:10.4018/jegr.2013040104.

understood by government and includes delivering and receiving information to and from members of the public who use Facebook and are interested in the project.

\section{Receiving and Relaying Emergency Information}

Twitter was noted to be useful for both receiving and relaying emergency information to citizens. One DIT participant suggested that early access via Twitter to breaking popular culture news helped demonstrate to others the potential of Twitter to rapidly notify agencies of more meaningful business-related information that was time sensitive. The Mayor's representative reported using Twitter to notify the public of emergency situations. Twitter was used as an online broadcast system to alert and update the public of a particular emergency, a tsunami warning in 2010, and ongoing developments as information surfaced.

Some participants followed other City and County of Honolulu Twitter accounts as a way to stay informed about emerging situations. In these cases re-tweets were used to share information with a wider audience. The Mayor's representative elaborated:

Basically, if it's information that I think needs to be shared, I'll re-tweet. Or maybe I'll even make a call to the Department that has provided the information, and ask them more about it. And kind of refine the message, and put it out another time...

The use of Twitter for relaying emergency information was determined to be dependent on departmental mission. While one department might have reported using Twitter to stay informed of emergencies, that process might end with that information receipt. In particular, it was suggested that departments whose missions are strictly concerned with transmitting emergency 
information are best suited to maximize Twitter use. A DBF participant examined potential Twitter use by other departments to relay emergency information:

[W]hen we had that Island-wide power outage. My understanding is that people were checking their Twitter feeds and finding out: it's everywhere, it was the entire island... Our civil defense guys, our police, they would have to actually go and send people out where it's happening. If they had developed their Twitter following, or their Twitter knowledge, then they could have just ... leveraged all that. And within a few minutes they could have probably realized that.

No official Department of Emergency Management Twitter account for the City and County of Honolulu existed at the time of study.

\section{Receiving and Responding to Public Comments}

While the primary use of Twitter was as a send, receive, and relay government-driven information portal, citizen requests for information did at times provide instances in which the government faced the need to respond. Questions from the public were elicited in light of government reports or emerging events. Such input requires development of protocols for response, even when comprehensive Twitter use policies have not been developed. A DDC representative described the following passive protocol:

Our current policy is we just refer them to our Customer Service Department, another City agency that takes all these customer questions. So there are people in the public that somehow see our Twitter account and, you know, they want an answer to what is the status of a project. But I was told not to go directly back to them. 
Harris, C. S., \& Winter, J. S. (2013). "Opening the flow of citizen engagement: An exploratory study of social networking services as a potential vehicle for e-participation in the City and County of Honolulu." International Journal of Electronic Government Research, 9(2), 63-84. doi:10.4018/jegr.2013040104.

Citizen information obtained through Twitter also included commentary. The Mayor's representative stated that, to date, the direct postings of commentary by citizen followers to the official account are often positive feedback or encouragement. The Mayor's representative also described forwarding selected comments to the Mayor:

[S]ometimes I would call to the Mayor's attention, something I had read... Like: 'Look at this use of alternative energy in Sacramento, California.' ...Or some reply that will take you with a link to an article, and I will print and share with him and others in the Administration: 'Hey, here is something that someone said we should look at.' And I don't know necessarily that's gone anywhere beyond that, because then it's kind of out of my view.

An extension to citizen commentary was further noted by several departments: occasionally citizens following a particular City and County operated Twitter account will re-tweet official City and County posted Twitter announcements. The Mayor's Office noted, "Initially it was experimental... 'Let's just see what we do with this. And, if we get any followers, if anybody cares.' And we found that it did. That people re-tweet our messages."

The DTS participant reported use of Facebook as a tool to receive and respond to public comments and questions. DTS also reported that it uses Facebook to connect with the general public, with an emphasis on younger citizens. Two-way-communication between government and citizens was reported at the minimal level of citizen-initiated question sending and government action of reviewing citizen comments.

\section{Key Benefits and Problems}


While no direct use of SNS for government policymaking was found at the time of this study, policymakers perceived several general problems and benefits of the use of Twitter and Facebook (Table 3). All of the departments cited near real-time information sources (emergencies, etc.) as one of the key benefits of government Twitter use. Events such as fiber cable breaks, tsunamis, earthquakes and general power outages, demonstrate how government can profit from utilizing citizen information available through Twitter. Another benefit was the capability to push key information that might otherwise face media edit. The Mayor's representative noted that it is a valuable supplement to the information covered in mainstream news due to editorial decisions. Government officials presented frustration with commercial news media editing or not reporting what is important but routine information.

One problem of Twitter use noted by multiple policymakers was the difficulty in validating the accuracy of source and information. Another problem of Twitter is a lack of feedback that information sent is useful. A DBF participant observed:

But, you know, what I really wonder is... am I just putting something out there and nobody is really listening? Are we getting the right sort of followers? So that they will actually go ahead and re-tweet, you know, to their followers. I haven't seen - when I look at the metrics and stuff, I haven't been too successful at that.

DTS's project-based Facebook effort was quite advanced relative to other departments' level of adoption and integration of SNS. The four other departments interviewed had mixed thoughts about expanding the use of SNS. Four policymakers cite a benefit of Facebook as the ability to reach segments of self-selected, interested parties. Alternatively, the ability for public dialogue was also regarded by government to lead to potential problems by creating avenues for unproductive critique. For instance, the DBF observed, 
Harris, C. S., \& Winter, J. S. (2013). "Opening the flow of citizen engagement: An exploratory study of social networking services as a potential vehicle for e-participation in the City and County of Honolulu." International Journal of Electronic Government Research, 9(2), 63-84. doi:10.4018/jegr.2013040104.

... what kind of interests me, yet scares me at the same time, about Facebook, is the ability to engage in a meaningful dialogue with folks who choose to follow you... Then, it becomes a little bit deep. You are a government entity. And, you want to keep things open. Yet, at the same time, do you want people ripping on you? ...That's my challenge right now. All the different scenarios and how we would respond to them, before we actually put out a Facebook page.

At the time of this study, no policies were in place for how to handle unproductive criticism.

Another benefit of both Twitter and Facebook was the ability to reach segments of self-selected, interested parties. Representatives of both the DIT and DTS noted the use of SNS as a means to reach younger participants.

Participants indicated the belief that future SNS adoption, expansion and innovative implementation will be slow and uneven across departments. Initiation of Twitter was perceived as a positive addition to deployed City and County communication platforms. However, its implementation was largely the result of the CIO's initiative and the Mayor's approval and support. There are indications that this effort will not continue to evolve without direction and guidance from the Office of the Mayor, particularly in light of the anticipated mayoral election approaching at the time of the study, and the then-unknown identity and attitude of the new Mayor. The DIT noted:

What we do in the IT is identify tools that could be useful for the City, and then present them to the leadership, and that would be the Mayor. It was the Mayor's decision to push this out as an initiative. So, as far as talking about the future, it's going to fall back on the 
next Mayor. So we will probably re-present it to the next person in charge and see what direction he will want to take us. Because he could say, no, we want to shut it off.

\section{Discussion and Analysis}

The City and County of Honolulu informally initiated use of SNS in 2008, and use remained at an early stage of integration into business processes and operations at the time of this study. Integration was primarily limited to designation of a trusted manager to administer SNS in each department. In this instance, a single champion spearheaded the effort but left departments with free reign. While interviewees conceived of innovative ways to improve government-citizen communication, in some cases, a lack of policy hindered development -- for example, reluctance to respond to citizen queries due to uncertainty about what would be officially acceptable. It is important to remember all interviewees acted as representatives of local government; as such, they were constrained by concern about legal aspects, unproductive critique, or uncertainty about who they were interacting with. In their analysis of European e-government initiatives, Eynon and Dutton (2007) found several legal barriers to enhanced government-citizen engagement, including increased liability risks, a lack of clear data protection guidelines for information sharing, and an absence of a general right for citizen-government communication. In the case of the City and County of Honolulu, a lack of internal organizational change to complement the use of networked ICT (e.g., the formation of specific policies governing management of, and response to, citizens' comments) constrained the ways in which ICTs could reshape citizengovernment communication.

One reason for the DIT's initial decision to foster departmental Twitter accounts was as a preventative measure against the development of counterfeit City and County agency Twitter accounts and to provide consistent naming conventions while the individual departments 
Harris, C. S., \& Winter, J. S. (2013). "Opening the flow of citizen engagement: An exploratory study of social networking services as a potential vehicle for e-participation in the City and County of Honolulu." International Journal of Electronic Government Research, 9(2), 63-84. doi:10.4018/jegr.2013040104.

considered their specific needs and mission. Each department did this autonomously. In contrast, to help develop a shared vision for how to better use new technology, the Department of Technology (DOT) for City of Columbus, Ohio created and sponsored an ad hoc "Social Media Group" comprised of representatives from city departments (Landsbergen, 2010).

DTS explained that Facebook was strategically used to reach younger adults, a demographic comprised of members of the Millennial generation, defined as the generational cohort born in the 1980s and1990s (Leyden \& Teixeira, 2007). Young adults are more likely to take part in political activities on social networking sites (Smith, 2009). By connecting with the Millennial and other cohorts of online political users, government could indirectly impact the policy cycle through providing a more informed public at the voting polls and/or other offline democratic forums.

In relation to receiving and relaying peer agency information, if the information shared between agencies was used as shared or learned knowledge, for example to leverage structural road development information shared via Twitter by another DDC agency for City road improvement purposes, then Twitter may be considered an example of ICT-enabled connected governance which contributes externally to providing innovation in service delivery. Such sharing of information could also lead to greater cross-government project collaboration and participation between agencies. However, unless the government is sharing this knowledge directly with citizens, for example re-tweeting the particular information, this use does not contribute to greater citizen empowerment or participation.

This concept of sharing information which otherwise might not be accessed via Twitter by particular citizens or citizen groups corresponds with Macintosh's (2004) first level of 
participation, e-enabling. Re-tweeting, checking for accuracy of the original message, and following-up on emerging details could possibly serve as key factors for governments to consider when providing or re-tweeting information to the public, especially in risk management situations.

One promising development was the emergence of feeds like ktlink, which provide examples of how Twitter is used by government as a platform for citizen or citizen-group to government communication via government receiving of information through actively seeking and following public feeds. At the same time, ktlink's existence provides an example of Twitter's capability to be leveraged by citizens to participate in the delivery of public information. On the other hand, ktlink's use of Twitter to provide the public with information gleaned from government websites, in this particular instance the Police Department, might suggest an area in which the government is failing to provide information of public interest and perhaps should consider utilizing Twitter, particularly to secure the validity of information delivered.

The DIT's examples of learning about a major fiber cable break and police incident reports reflect the value of near real-time information obtained by following different private and citizen-based entities on Twitter. Further, these examples provide insight as to how citizen participation on Twitter can directly impact government awareness and action regarding emerging situations occurring in the community. Such information might otherwise not be brought to government attention promptly, if at all. This is not to indicate that government should react reflexively to all information received through Twitter or other SNS platforms. As several participants noted, SNS information can be inaccurate or fictitious. It is vital for government to validate information it receives on Twitter to insure that the information is 
Harris, C. S., \& Winter, J. S. (2013). "Opening the flow of citizen engagement: An exploratory study of social networking services as a potential vehicle for e-participation in the City and County of Honolulu." International Journal of Electronic Government Research, 9(2), 63-84. doi:10.4018/jegr.2013040104.

accurate, prior to acting and potentially wasting time and resources or even putting the public in danger.

The DDC's use of Twitter as a one-way communication tool to push information about road closures to the public corresponds with the first level of Macintosh's levels of engagement, eenabling, and with the OECD's (2001) informational level. Multiple statements by officials established harmony between the level's dual concept of the government provision of "passive" information as demanded by citizens and "active" actions to propagate information to citizens (OECD 2003). Actions taken by different departments to provide citizens with relevant information regarding current activities and deadlines via Twitter updates can be categorized in the "active". While the majority of governmental use of Twitter seems to fall within the category of "active", a DIT representative described Twitter use as a response portal to citizen requests for more "passive" information: "For example, we were involved in applying for the Google "Broadband" grant. And so, we were getting a lot of calls. And the way I responded was: 'Just look at Twitter, and we will tell you what happened."' The use of Twitter to provide government information to citizens aligns with the first level of participation, e-enabling. For instance, in the conversation regarding pushing information to citizens, the DDC representative suggested that government pushing of information on Twitter provided a one-stop alternative for citizens who might normally search multiple online and offline platforms, or who may not normally receive the information. This use of Twitter met the e-enabling level by allowing citizens to take advantage of large amounts of government information by consolidating selected, relevant information in one place. 
Similarly, the DTS' use of Facebook, in concert with Twitter, YouTube and Vimeo, to push information to interested parties can be viewed as a one-way communication tool in that it focuses on a government-to-citizen flow of information. As with Twitter, this corresponds with the first level of engagement. The information provided was then used by participants as a means to become or stay informed on policy, and perhaps be better able to use specific knowledge to more directly participate in the decision process through traditional forums such as elections. However, not all members of this group may feel the need or comfort level to leave a comment. If government narrows its information to respond only to questions asked, it risks failing to provide other valuable information to the public.

In regards to receiving and relaying emergency information, Twitter's role as an internal tool may facilitate connected governance by efficient receipt of, processing of, and meaningful reaction to emerging emergencies. It follows that well-planned integration into specific government business processes is key to success.

The Mayor's representative's retweeting and refinement of Twitter messages corresponds with two of the OECD's (2003) stated objectives of technology-enabled information dissemination, consultation, and participation for the improvement of the policy-making process: reaching and engaging a wider audience and providing relevant information. Regarding emergency management, these two objectives primarily related to the enabling of information dissemination and were not being used for consultation and participation.

No official Department of Emergency Management Twitter account for the City and County of Honolulu existed at the time of study. Such a feed might be an important instrument to develop to harness the capacity of SNS. As the present objective of government Twitter use is to receive 
Harris, C. S., \& Winter, J. S. (2013). "Opening the flow of citizen engagement: An exploratory study of social networking services as a potential vehicle for e-participation in the City and County of Honolulu." International Journal of Electronic Government Research, 9(2), 63-84. doi:10.4018/jegr.2013040104.

and relay emergency information to citizens, City and County of Honolulu Twitter initiatives were not perceived as directly e-participation focused.

On the other hand, re-tweeting of official government messages is seen as a citizen-led form of participation. By re-tweeting government messages, citizens are perceived as being both interested in or concerned with the information provided. Further, in sharing information with others, the reach of the original message is expanded to individuals who are on Twitter, but may not be following the government site. San Francisco acknowledged that in the city's SF311 service, which allows citizens to send short Tweets requesting city services such as fixing potholes, ran the danger of creating unrealistic expectants about the government's ability to respond. At the same time, it was believed that the information was still useful in its ability to be used to inform collective discussion relating to City's resources and spending priorities rendered (Landsbergen, 2010).

Through responding to citizen questions directly, or by forwarding the question to the appropriate information source, DTS supported two-way-communication between the public and government. However, DTS did not report directly engaging citizens in the overall policy process of the project. Accordingly, government use of Facebook to provide information to the public is presently at the first level of participation as defined by Macintosh (2004), e-enabling. Although Facebook was used at times in manners consistent with two-way communication, it did not seem to directly support the second level of participation, e-engaging, since communication was still informational.

\section{Integration of SNS into policymaking}


While no evidence was found during this early stage that SNS tools were explicitly employed in the policymaking process by any stakeholder, or that policymakers were using SNS to directly promote e-participation initiatives, several potential future opportunities were noted. At the time of the study, government-operated SNS was primarily used by policymakers as a one-wayinformation-based government service. Following the network society perspective, it is important to consider that the provision of Web 2.0 services does not necessarily make government more participatory. These tools may enhance two-way communication under certain conditions, but they may also be used for more traditional one-way, "push" communications (e.g., press releases, broadcast media, PSAs). While to some these represent the means for engagement, unless organizational processes are transformed, policymakers may act as though these are simply another form of broadcast media. Regarding the specific level of policymaking participation promoted by Twitter, pushing information out implies the indirect e-enabling of citizens by facilitating an informed citizenry to better guide actions in such traditional democratic venues as the electoral process and City Council meetings. However, there was no report of targeting policymaking issues with this information.

Alternatively, the reported project-specific nature of Facebook utilization was more conducive to targeting policy decisions. This use was differentiated from Twitter in light of the two-way communication link. However, again no direct intent to incorporate such participation into the policymaking process was evident. No evidence was reported that the City and County of Honolulu had integrated SNS into the policymaking life cycle. Nor was evidence reported that the City and County of Honolulu was using Twitter to directly promote citizen participation. However, some evidence was reported that Facebook was being used to promote an early stage 
Harris, C. S., \& Winter, J. S. (2013). "Opening the flow of citizen engagement: An exploratory study of social networking services as a potential vehicle for e-participation in the City and County of Honolulu." International Journal of Electronic Government Research, 9(2), 63-84. doi:10.4018/jegr.2013040104.

of citizen participation. The provision of interactive online platforms allows for citizens to conveniently obtain information that matters to them (Mossberger \& Jimenez, 2009).

The difficulty in validating the accuracy of source and information noted by several policymakers' points to a potentially serious trust problem as government use of Twitter matures and is incorporated into citizen participation in processes up to, and including, policymaking. If the source of information gleaned from Twitter is not reliably known, then the material provided might not be trusted, and any effort to encourage citizen participation would be undermined.

At the same time, real-time information sources provided by citizens demonstrate how government can profit from utilizing citizen information available through Twitter. While these are operations-based, it is not a huge leap from operational decision making to policymaking, in the sense that knowledge by constituents can be a vital input for policymakers to have in understanding and measuring results desired from formulated policies.

Further, relative to the agenda-setting stage of the policymaking process, government use of Twitter could be leveraged as a way to keep the public informed on particular policy issues, which may otherwise not be covered by the local media. However, uncertainty that information output being broadcast is received and listened to by citizens is also relevant to the engagement of citizens in the policymaking process. It is important for government to find ways to assess whether the constituency is engaged. Integrating Macintosh's (2004) framework into future assessment will allow both the City and County to evaluate progress over time as well as to make meaningful comparisons with other municipalities. 
A unique benefit of Facebook is its capacity to be used as an extension of an official webpage with dialogue capabilities. If used to promote dialogue with and among citizen users, government use of Facebook could potentially support all three levels of participation as defined by Macintosh (2004). Support of e-enabling could occur through the provision of information in a readily-available online forum; support of e-engaging could occur through the promotion of citizen dialogue on Facebook; and support of e-empowering could occur through promoting citizen-based idea sharing in the setting of a policy agenda. Further, Smith (2009) found that young adults are more likely to take part in political activity on SNS. In a future policy-setting process, this more widely cast net for input might provide a stronger policy decision process by including demographic segments not reached by traditional means.

In order for Facebook to be a viable vehicle for participation in policymaking, protocols must be developed to manage potential pitfalls such as the drain in resources as a result of unproductive critiques. An example of government use of SNS to engage the public regarding government spending is the United Kingdom's (UK) "Spending Challenge" campaign, implemented for crowd-sourcing for public-based policy ideas and solutions. In 2010, the economics and finance ministry of the U.K. invited the public to submit ideas and solutions, as well as to discuss and debate spending priorities (HM Treasury, 9 July 2010). One problem that materialized during the "Spending Challenge" was the submission of malicious commentary (Toynbee, 24 August 2010). As this was one of the worries of the City and County of Honolulu SNS managers, it should be noted as an issue that ought to be prepared for across departments.

In August 2012, following the conclusion of this study, a lawsuit was filed against the City and County of Honolulu alleging that the City violated the First Amendment to the United States Constitution by removing comments posted by particular individuals on the Honolulu Police 
Harris, C. S., \& Winter, J. S. (2013). "Opening the flow of citizen engagement: An exploratory study of social networking services as a potential vehicle for e-participation in the City and County of Honolulu." International Journal of Electronic Government Research, 9(2), 63-84. doi:10.4018/jegr.2013040104.

Department's (HPD) official Facebook page and banning those who made comments that are unfavorable to the department (Bright, 2012). According to news reports, the lawsuit could set a legal precedent as perhaps one of the first in the United States to deal with deleted social media posts (Associated Press, 2012). While the lawsuit is still pending, follow-up research relating to the case's outcome could provide insight into the rulings potential implications on the future of government SNS use and or management.

In assessing their individual capabilities to safely and effectively handle these and other challenges, government can decide whether or not to deploy SNS strategies in the policymaking process. Deciding how to deploy SNS processes must also include determining the level in the policy cycle at which government can and desires to encourage participation. Landsbergen (2010) found that concern was raised by some City of Columbus, Ohio departments regarding the affordance of time allocation needed to support an added media outlet. Other suggested concern was in regards to the possibility of higher expectations for direct response and requests of information.

These findings illustrate that there is no single solution for municipal governments. Following the network society perspective, governments cannot merely tack on ICT to existing services but must take steps to transform the organization to make use of the potentials of new and future ICT. Based on the experience with Twitter deployment, no marked enhancements or innovations in SNS application are likely to occur organization-wide without a similar or more rigorous initiative from the DIT with support of the new Mayor. This instability could in turn deter future citizen use of such tools. In order to provide stability, policy should be developed to provide consistency of use across administrations, specifically what is to occur with the informational 
history posted via SNS from one administration to the next. Policy should also be considered to protect the overall mission of the institution. Policies should be flexible in order to meet the needs of the varying departmental missions as well as to respond to emerging technological developments and applications of SNS. Further, safeguards and protocols should be developed to ensure both government and citizen stakeholders of the reliability and security of participation using SNS.

\section{Conclusions}

This study explored the current use of SNS by City and County of Honolulu policymakers, looking at early adopters in government and their use of social media to interact with citizens. Specifically, it sought to provide a better understanding of stakeholders' perceptions of local eparticipation through government-operated SNS. This research investigated opportunities and barriers to implementing SNS as potential platforms for e-participation in the City and County of Honolulu. A number of benefits and challenges to government utilization of SNS were identified. For government officials, there existed a spectrum of desired expectations regarding future development of SNS. As more government bodies decide to adopt or continue to use SNS to engage with citizens it is important to understand how to leverage these services. Addressing these issues will be essential in any further evolution. This will require a more formal pilot study that provides opportunity for systematic evaluation of SNS initiatives, addressing the perspectives of multiple stakeholders (e.g., citizen users and non-users).

One practical suggestion from this research is the need for greater support in planning, implementation, and management of SNS. The development of a new or enhanced City and County comprehensive communication plan could provide coordinated guidance and direction for internal and external communications. Key aims of the plan should include the provision of a 
Harris, C. S., \& Winter, J. S. (2013). "Opening the flow of citizen engagement: An exploratory study of social networking services as a potential vehicle for e-participation in the City and County of Honolulu." International Journal of Electronic Government Research, 9(2), 63-84. doi:10.4018/jegr.2013040104.

transparent document designed to inform stakeholders of policies; identification and incorporation of best practices from other organizations, and a focus on SNS utilizations that could increase government productivity, such as tweeting appropriate information to interested constituents or contractors on a programmed or one-time basis as opposed to responding many times to separate inquiries. This plan would also act as a vehicle to ensure ongoing, informed consideration of communication policies and practices over time, as technologies and levels of available resources change. Now that the initial pilot stage is complete, creating a municipalitywide task force to facilitate collaborative development regarding policy and use, while still focusing on the individual context of units, is essential.

The City and County leadership (two different mayors working with one CIO) served as able champions of networked governance. The City and County moved quickly from the exploratory phase, reviewing lessons learned from the original SNS initiative. A follow-up interview with the City and County of Honolulu's Chief Information Officer (CIO) in 2011 revealed that the City and County continues to market SNS use internally. Departmental use of SNS has expanded, with growing use of both Twitter and Facebook. According to its website, the City and County maintained 18 Twitter accounts and 11 Facebook accounts as of December, 2011. The CIO elaborated that SNS were used extensively to coordinate the 2011 Asia-Pacific Cooperation (APEC) Conference, which was held in Honolulu on November, 2011. Notably, in 2011, the City and County was selected to be a 2012 Code for America City, and it will receive a year of intensive technical assistance from the Code for America Fellows (City and County of Honolulu, 2011). Code for America is a nonprofit program that recruits fellows to be attached to 
a selected city for the year in order to introduce innovative technology- based applications for city governments.

In preparation for the 2012 Code for America cities, the City and County held CityCamp Honolulu, on December 3, 2011. CityCamp Honolulu was structured as an "unconference" in order to promote engagement and innovative ideas from both private and public sector participants. Citizens actively attended and generated ideas for government and private-sector initiatives. Using both online and offline engagement platforms the event sought to identify potential applications that the City and County should prioritize. Ideas for improvements were crowd-sourced from citizens and voted upon online. Later, ideas were voted upon in person and participants broke out into groups to brainstorm and provide feedback on selected ideas. As an extension of the CityCamp Honolulu initiative, a "civic hackathon" was also initiated in January 2012.

The CIO emphasized that the learning process related to SNS use by the City and County is ongoing. He stated, "we are really trying to change the way government and the citizen interact from a 'wait till they come' to a 'let us provide you with this to help you' style." Continued evaluation of the City and County use of SNS is recommended to provide for longitudinal analysis of potential growth in levels of e-participation.

Through use of a network society lens, it was revealed that in many instances internal organizational configurations and practices did not yet meet the promise of SNS's ability to promote new forms of networked relationships between governments and citizens (specifically, the two-way communication described by Macintosh (2004) as e-engaging and e-empowering). As governments around the world continue to evaluate and integrate SNS into their communication processes, this research will assist in the understanding of SNS use by local 
Harris, C. S., \& Winter, J. S. (2013). "Opening the flow of citizen engagement: An exploratory study of social networking services as a potential vehicle for e-participation in the City and County of Honolulu." International Journal of Electronic Government Research, 9(2), 63-84. doi:10.4018/jegr.2013040104.

government, adding to both theoretical and pragmatic understanding of unique, as well as common, opportunities and barriers to implementing SNS as potential platforms for eparticipation. This study adds to the academic field of e-government through the provision of insight into stakeholders' perceptions of local e-participation through government-operated SNS, and it may be useful to policymakers looking to utilize SNS to promote citizen participation in the policymaking process.

These findings also add support to the sociotechnical systems approach (Kling, 2000; Sæbø et al., 2009), which argues that, due to the combination of equipment, people, and governance structures, ICT policies differed from one city to the next, growth in SNS is driven by technical, social, economic and institutional forces. While local governments share some of the egovernment requirements with those at the national level, they also maintain specific requirements that are either unique to their contexts or stipulate greater examination (Löfstedt, 2005). The provision of interactive online platforms allows for citizens to conveniently obtain information that matters to them (Mossberger \& Jimenez, 2009). The underutilization of SNS, such as Facebook and Twitter, by municipal government for civic engagement is suggested as potentially being a temporary phenomenon, allowing time for experimentation and analysis of contribution to citizen knowledge and participation (Mossberger \& Jimenez, 2009). Thus, continued study and analysis is suggested as government agencies moves forward in the decision of future SNS use.

\footnotetext{
${ }^{1}$ Because this study addressed an informal government pilot, not all areas of the framework were integrated.
} 


\section{References}

Arjuna, T., Padovani, C., \& Nesti, G. (2007). Communication (e)democracy: Assessing European e-democracy discourses. In B. Cammaerts and N. Carpentier (Eds.), Reclaiming the media: Communication rights \& democratic media roles (pp. 31-65). Bristol, UK: Intellect.

Associated Press. (22 August 2012). Lawsuit over HPD Facebook comments could set legal precedent. Retrieved on September 7, 2012, from http://www.staradvertiser.com/news/ breaking/167107435.html?id=167107435.

Bertot, J., Jaeger, C., \& McClure, C. (2008). Citizen-centered e-government services: Benefits, costs, and research needs. Paper presented at the $9^{\text {th }}$ Annual International Digital Government Research Conference, Montreal, 18-21 May.

Boyd, O. (2008). Differences in edemocracy parties' eparticipation systems. Information Polity, 13(3/4), 167-188.

Brewer, G., Neubauer, B., \& Geiselhart, K. (2006). Designing and implementing e-government systems: Critical implications for public administration and democracy. Administration \& Society, 38(4), 472-499.

Bright, A. (28 August 2012). How do you say 'public forum doctrine' in Hawaiian? Hawai ‘ $i$ Free Press. Retrieved on August 28, 2012, from http://www.hawaiifreepress.com/ ArticlesMain/tabid/56/articleType/ArticleView/articleId/7584/How-Do-You-Say-PublicForum-Doctrine-in-Hawaiian.aspx

Budinoski, K., \& Trajkovik, V. (2012). Incorporating social network services in eGovernment solutions: A case study. European Journal of ePractice, 2012(16), 58- 70. 
Harris, C. S., \& Winter, J. S. (2013). “Opening the flow of citizen engagement: An exploratory study of social networking services as a potential vehicle for e-participation in the City and County of Honolulu." International Journal of Electronic Government Research, 9(2), 63-84. doi:10.4018/jegr.2013040104.

Buhl, H.U. (2011). From revolution to participation: Social media and the democratic decisionmaking process. Business \& Information Systems Engineering, 2011(4), 195-198.

Castells, M. (1996). The rise of the network society. Oxford: Blackwell.

Castells, M. (2009). Communication power. New York: Oxford University Press.

Charalabidis, Y., Loukis, E., \& Kleinsfeld, R. (2012). Towards a rationalisation of social media exploitation in government policy-making processes. European Journal of ePractice, 2012(16), 77- 93.

Chun, S.A., Shulman, S., Sandoval, R., \& Hovy, E. (2010). Government 2.0: Making connections between citizens, data and government. Information Polity, 15, 1-9.

City and County of Honolulu. (19 October, 2011). Citycamp Honolulu aims for innovation, transparency. Retrieved December 12, 2011, from http://www1.honolulu.gov/csd/publiccom/honnews11/CityCampHNL19Oct11.htm.

Creswell, J.W. (1998). Qualitative inquiry and research design: Choosing among five approaches. Thousand Oaks, CA: Sage.

Eynon, R., \& Dutton, W. (2007). Barriers to networked governments: Evidence from Europe. Prometheus, 25(3), 225-242.

Harris, L., \& Vincent, J. (2008). Effective use of mobile communications in e-government: How do we reach the tipping point? Information, Communication \& Society, 11(3), 395-413.

HM Treasury. (9 July 2010). The Chancellor launches the Spending Challenge. Retrieved October 29, 2010, from http://www.hm-treasury.gov.uk/press_23_10.htm 
Kling, R. (2000). Learning about information technologies and social change: The contribution of social informatics, The Information Society, 16(3), 217-232.

Lacigova, O., Maizite, A., \& Cave, B. (2012). eParticipation and Social Media: a Symbiotic Relationship. European Journal of ePractice, 012(16), 71-76.

Landsbergen, D. (2010). Government as part of the revolution: Using social media to achieve public goals. Electronic Journal of e-Government, 8(2), 135-147.

Lappas, G. (2008). An overview of web mining in societal benefit areas. Online Information Review, 32(2), 179-195.

Leyden, P., \& Teixeira, R. (2007). The progressive politics of the Millennial Generation: The emerging evidence on why the younger generation is boosting progressive prospects for the early $21^{\text {st }}$ Century. San Francisco, CA: NPI.

Lips, M. (2010). Rethinking citizen-government relationships in the age of digital identity: Insights from research. Information Policy, 15, 273-289.

Löfstedt, U. (2005). E-government: Assessment of current research and some proposals for future direction. International Journal of Public Information Systems, 1: 39-52.

Macintosh, A. (2004). Characterizing e-participation in policy-making. Paper presented at the $37^{\text {th }}$ Hawaii International Conference on System Science, Kona, Hawaii 5-8 January.

Macintosh, A., \& Whyte, A. (2008). Towards an evaluation framework for e-participation. Transforming Government: People, Process \& Policy, 2(1), 16-30.

Mann, H., Grant, G., \& Mann I.J.S. (2011). City e-government: Scope and its realization. International Journal of Electronic Government Research, 7(1), 38-50. 
Harris, C. S., \& Winter, J. S. (2013). “Opening the flow of citizen engagement: An exploratory study of social networking services as a potential vehicle for e-participation in the City and County of Honolulu." International Journal of Electronic Government Research, 9(2), 63-84. doi:10.4018/jegr.2013040104.

Mossberger, K., \& Jiminez, B. (2009). Can e-government promote civic engagement?: A study of local government websites in Illinois and the U.S. Institute for Policy and Civic Engagement, University of Illinois at Chicago. Retrieved December 12, 2011, from http://www.uic.edu/cuppa/ipce/egovtreportfinal.pdf

Mota, J.C., \& Santinha, G. (2012). Social media and civic engagement: Discussing the case of Aveiro, Portugal. European Journal of ePractice, 2012(16), 29-41.

Nachmias, D., \& Rotem, A. (2007). E-Participation in Israeli local governments: A comparative analysis. Paper presented at the 7th European Conference on E-Government, The Hague, 21-22 June.

Organization for Economic Co-Operation and Development. (2001). Citizens as partners: OECD handbook on information, consultation, and public participation in policy-making. Paris: OECD.

Organization for Economic Co-Operation and Development. (2003). Promise and problems of edemocracy: Challenges of online citizen engagement. Paris: OECD.

Panagiotopoulos, P., \& Sams, S. (2011). Twitter in local government: A study of greater London authorities. Pre-ICIS Workshop: Open Innovation in eGovernment. Shanghai, 2011.

Papacharissi, Z. (2009). The virtual geographies of social networks: A comparative analysis of Facebook, LinkedIn, and ASmallWorld. New Media \& Society, 11: 199-220.

Phelan, O., McCarthy, K. \& Smyth, B. (2009). Using Twitter to recommend real-time topical news. Paper presented at the 3rd ACM Conference on Recommender Systems, New York, 22-25 October. 
Pinch, T.J., \& Bijker, W.E. (1987). The social construction of facts and artifacts: Or how the sociology of science and the sociology of technology might benefit each other. In W.E. Bijker, T.P. Hughes \& T.J. Pinch (Eds.), The social construction of technological systems: New directions in the sociology and history of technology (pp. 17-50). Cambridge, MA: MIT Press.

Platte, M. (30 March 2008). All sides of rail debate presented. Honolulu Advertiser. Retrieved on February 13, 2011, from http://he.honoluluadvertiser.com/article/2008/Mar/30/op/ hawaii803300337.html

Robertson, S., Vatrapu, R., \& Medina, R. (2009). The social life of social networks: Facebook linkage patterns in the 2008 U.S. presidential election. Paper presented at the $10^{\text {th }}$ International Digital Government Research Conference, Puebla, Mexico, 17-21 May.

Romsdahl, R.J. (2005). Political deliberation and e-participation in policy-making. CLCWeb: Comparative Literature and Culture, 7(2). Retrieved on August 12, 2012, from http://docs.lib.purdue.edu/clcweb/vol7/iss2/7/

Roy, J. (2012). Social media's democratic paradox: Lessons from Canada. European Journal of ePractice, 2012(16), 5-15.

Sæbø, Ø, Rose, J., \& Nyvang, T. (2009). The role of social networking services. In A. Macintosh and E. Tambouris (Eds.), Electronic Participation (pp. 46-55). Heidelberg: SpringerVerlag.

Scott, J. (2006). "E” the People: Do U.S. municipal government web sites support public involvement? Public Administration Review, 66(3), 341-353.

Smith, A. (2009). The Internet's role in Campaign 2008. Washington, DC: Pew Research Center. 
Harris, C. S., \& Winter, J. S. (2013). "Opening the flow of citizen engagement: An exploratory study of social networking services as a potential vehicle for e-participation in the City and County of Honolulu." International Journal of Electronic Government Research, 9(2), 63-84. doi:10.4018/jegr.2013040104.

Stake, R.E. (1995). The art of case study research. Thousand Oaks, CA; Sage.

Tambouris, E., Liotas, N., \& Tarabanis, K. (2007). A framework for assessing eparticipation projects and tools. Paper presented at the $40^{\text {th }}$ Hawaii International Conference on System Sciences, Waikoloa, Hawaii, 3-6 January.

Taylor-Smith, E., \& Lindner, R. (2009). Using social networking tools to eparticipation initiatives. In A. Prosser and P. Parycek (Eds.), Proceedings of EDEM 2009 Conference on Electronic Democracy (pp. 115 -121). Vienna: Austrian Computer Society.

Toynbee, P. (24 August 2010). Loyal public service merits more than this cold trashing. The Guardian. Retrieved on October 25, 2010, from http://www.guardian.co.uk/ commentisfree/2010/aug/24/public-service-merits-more-than-trashing.

The United Nation Department of Economic and Social Affairs Division for Public Administration and Development Management. (2008). United Nations e-government survey 2008: From e-government to connected governance. New York: United Nations. 
Table 1. Overview of Interview Questions Aligned with Macintosh's (2004) Framework

\begin{tabular}{|c|c|}
\hline & Rationale for using SNS to promote participation \\
\hline 1 & Do you have a Facebook/Twitter account for your City and County of Honolulu Department? \\
\hline 2 & $\begin{array}{l}\text { When did you start using the (Facebook) account/s? } \\
\text { a. What are the main uses of Facebook? } \\
\text { b. How have you currently integrated Facebook into your organization? }\end{array}$ \\
\hline 3 & $\begin{array}{l}\text { When did you decide to create a Twitter account? } \\
\text { a. What are the main uses of Twitter? } \\
\text { b. How have you currently Integrated Twitter into your organization? }\end{array}$ \\
\hline \multirow[t]{2}{*}{4} & $\begin{array}{l}\text { Do you have any other type of Social Networking Service account for your City and County Department? } \\
\text { a. If yes, please note the name of the service(s)? } \\
\text { b. What are the main uses for this service(s)? }\end{array}$ \\
\hline & SNS integration at each stage of the policymaking process \\
\hline \multirow[t]{2}{*}{5} & $\begin{array}{l}\text { How do you use the information received from Facebook/Twitter? } \\
\text { a. Does the information vary according to a particular issue or topic? If so, how? }\end{array}$ \\
\hline & Level of citizen participation promoted \\
\hline 6 & What types of information do you receive from Facebook/ Twitter? \\
\hline \multirow[t]{2}{*}{7} & $\begin{array}{l}\text { What important differences, if any, are there between information received through Facebook/Twitter and } \\
\text { information received through other methods? }\end{array}$ \\
\hline & Perceptions of main problems and benefits to SNS Deployment \\
\hline 8 & What are the main problems that you face currently (would you foresee) using Facebook? \\
\hline 9 & What would you describe (would you foresee) as the benefits of using Facebook? \\
\hline \multirow[t]{2}{*}{10} & What are the main problems that you face currently using Twitter? \\
\hline & Future plans to integrate SNS \\
\hline 11 & Do you have plans to (further) integrate Facebook in the future of your organization? \\
\hline 12 & Do you have plans to further integrate Twitter in the future of your organization? \\
\hline 13 & Do you have any other type of Social Networking Service account for your City and County Department? \\
\hline 14 & $\begin{array}{l}\text { How do you think that the City and County of Honolulu will integrate Social Networking Services in the } \\
\text { future? }\end{array}$ \\
\hline
\end{tabular}


Harris, C. S., \& Winter, J. S. (2013). "Opening the flow of citizen engagement: An exploratory study of social networking services as a potential vehicle for e-participation in the City and County of Honolulu." International Journal of Electronic Government Research, 9(2), 63-84. doi:10.4018/jegr.2013040104.

Table 2. Current Uses of SNS

\begin{tabular}{|c|c|c|c|c|c|}
\hline & Mayor & DIT & DBF & DDC & DTS \\
\hline Internal communication & & Twitter & & Twitter & \\
\hline Receive peer information & Twitter & Twitter & & Twitter & \\
\hline Receive/relay professional updates & & Twitter & & Twitter & \\
\hline Monitor breaking news & & & Twitter & & \\
\hline Push information to public/peers & Twitter & Twitter & Twitter & Twitter & $\begin{array}{c}\text { Twitter } \\
\text { Facebook }\end{array}$ \\
\hline Educate general public & & & & & $\begin{array}{c}\text { Twitter } \\
\text { Facebook }\end{array}$ \\
\hline Receive/relay emergency information & Twitter & Twitter & & & \\
\hline Receive public comment/questions & Twitter & Twitter & & Twitter & $\begin{array}{c}\text { Twitter } \\
\text { Facebook }\end{array}$ \\
\hline Respond to public comment/ questions & & & & & $\begin{array}{c}\text { Twitter } \\
\text { Facebook }\end{array}$ \\
\hline
\end{tabular}


Table 3. Benefits of SNS

\begin{tabular}{|c|c|c|c|c|c|}
\hline & Mayor & DIT & DBF & DDC & DTS \\
\hline Real-time information & Twitter & Twitter & Twitter & Twitter & Twitter \\
\hline One to Many communication & Twitter & Twitter & & Twitter & \\
\hline $\begin{array}{l}\text { Audience of self-selected interested } \\
\text { parties }\end{array}$ & $\begin{array}{l}\text { Twitter } \\
\text { Facebook }\end{array}$ & $\begin{array}{l}\text { Twitter } \\
\text { Facebook }\end{array}$ & Facebook & & $\begin{array}{l}\text { Twitter } \\
\text { Facebook }\end{array}$ \\
\hline Peer agencies/professional updates & Twitter & & & Twitter & \\
\hline $\begin{array}{l}\text { Push key information that might face } \\
\text { media edits }\end{array}$ & Twitter & & & Twitter & \\
\hline Audience beyond City and County & Twitter & & & Twitter & \\
\hline $\begin{array}{l}\text { Monitoring of news without active } \\
\text { search }\end{array}$ & Twitter & & Twitter & & \\
\hline $\begin{array}{l}\text { Provides feedback to inform project } \\
\text { message }\end{array}$ & & & & & Facebook \\
\hline Extension of official webpage & & & Facebook & & Facebook \\
\hline Serves as a "living document"/ archive & & & & & Facebook \\
\hline
\end{tabular}


Post-print

Harris, C. S., \& Winter, J. S. (2013). "Opening the flow of citizen engagement: An exploratory study of social networking services as a potential vehicle for e-participation in the City and County of Honolulu." International Journal of Electronic Government Research, 9(2), 63-84. doi:10.4018/jegr.2013040104.

Table 4. Problems of SNS

\begin{tabular}{|c|c|c|c|c|c|}
\hline & Mayor & DIT & DBF & DDC & DTS \\
\hline Difficulty verifying source & & $\begin{array}{l}\text { Twitter } \\
\text { Facebook }\end{array}$ & Twitter & & \\
\hline $\begin{array}{l}\text { Difficulty validating accuracy of } \\
\text { information }\end{array}$ & & $\begin{array}{l}\text { Twitter } \\
\text { Facebook }\end{array}$ & Twitter & Twitter & \\
\hline Resources needed to manage account & $\begin{array}{l}\text { Twitter } \\
\text { Facebook }\end{array}$ & Twitter & Twitter & Twitter & \\
\hline Departments slow to adopt & Twitter & $\begin{array}{l}\text { Twitter } \\
\text { Facebook }\end{array}$ & Facebook & & \\
\hline $\begin{array}{l}\text { Complicates coordination of consistent } \\
\text { message }\end{array}$ & & Twitter & & & \\
\hline $\begin{array}{l}\text { Lack of feedback that information sent } \\
\text { is useful }\end{array}$ & & & Twitter & Twitter & \\
\hline $\begin{array}{l}\text { Confusion between official operations } \\
\text { and political activities }\end{array}$ & Twitter & Twitter & & Twitter & \\
\hline 140 character limitation & Twitter & & & Twitter & Twitter \\
\hline $\begin{array}{l}\text { Adds to government information } \\
\text { overload }\end{array}$ & & & & Twitter & \\
\hline Keeping information fresh & & & Facebook & & Facebook \\
\hline Avenue for unproductive critique & & & Facebook & & \\
\hline Lack of policies & & & Facebook & & \\
\hline Difficulty understanding best use & & Facebook & & & \\
\hline $\begin{array}{l}\text { Internal resistance by non-technical } \\
\text { users/audience }\end{array}$ & & Facebook & & & \\
\hline
\end{tabular}

